\title{
Text, Context and Sex: \\ Gender Construction and Religious Identity in Robert Musil's Unions
}

R A M O N R.W. KIR S C H

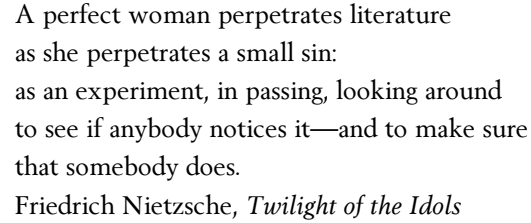

Claudine and Veronica were perfect women. Claudine was sexually promiscuous. Perfecting her second marriage consumed her energy as she struggled between the deep mystical union and love she shared with her husband and the physical desire she felt for other nameless men who preyed on her in transient environments. Veiled Veronica the Virgin was tempted to give up her self-imposed hermitage for the love of a real man, yet quietly, determinedly she chose to remain in the confines of her cold, dark, and damp habitat and to give her love to the illusory man. These women are main characters in Unions, a collection of two novellas (The Perfecting of a Love and The Temptation of Quiet Veronica) by the Austrian writer Robert Musil (1880-1942) published in 1911. Musil, best known for his unfinished magnum opus, The Man Without Qualities, is considered a central figure in the modernist and early postmodernist movements in the development of twentieth-century literature (see Poupard, 223ff). Literary critics have likened Musil's style of writing, in Unions in particular, to impressionism, with a stream of consciousness style whose closest comparison is James Joyce or Gertrude Stein (see Peacock 255). In twentieth-century literary criticism, Musil is noted for his contribution to the history of modern identity (see Johnson). I will explore the 
function of Unions as it represents spaces of religious identity tied to gendered erotic and mystical experiences.

I begin with the assumption that moral philosophies within culture are often transmitted at the popular level via such vehicles as literature. I also begin with the assumption that discourse within a culture can often be identified via these forms of popular culture. And finally, I begin with the knowledge that Musil is seen as one of the most observant writers of the twentieth century, continuously praised for his perceptions of society and his particular focus upon identity (both internal and external). ${ }^{1}$ His diaries as well as his literary works are valued for their ability to express vividly "the things that preoccupied men and women" during his lifetime: love, sex, morals, philosophy, psychology, politics, society, art, culture, science, human relationships, and religion (Payne xxii). The cast of characters one finds in Musil's writings represent a plethora of "attitudes within society at large" (Payne xxxi). It is for this reason that Musil is an excellent choice in exploring literary representations of gender construction and religious identity in early twentieth-century Central Europe. Hence, the question I have in this examination is: what do these early twentieth-century novellas tell us about gender construction and religious identity in the waning days of Central European Imperial culture? In answering this question I will limit my examination to the literary function of these novellas.

I enter the material with three primary categories in mind: text, context, and sex - what do the texts themselves tell us of religion and gender? What does the context in which the novella was written tell us about religion and gender? How does the text and context display sex and what do these displays tell us about gendered relationships and religious identity in early twentieth-century Central Europe? I will show that Unions tells us a great deal about the religious economy of early twentieth-century Central Europe.

Religious economy has been defined as, and is understood here as, "a subsystem of all social systems within a society" and it "encompasses all of the religious activity going on in any society" (Stark and Fink 35). ${ }^{2}$ These novellas illustrate one activity making up the early twentieth-century Central European religious economic landscape, that is, a gendered religious identity that included erotic and sensual experiences with a divine presence.

In The Perfecting of a Love (henceforth Perfecting), Claudine, the central character, after spending yet another blissful night in the arms of her husband, travels alone to see her daughter in a boarding school. During the trip, she reflects on the love of her husband, her past sexual life and entertains the possibility of having an affair with a man with whom she is travelling. After much internal and demanding dialogue, being stranded by a snowstorm, and in the process forgetting 
to see her daughter, Claudine has sexual intercourse with the man and considers this an act that affirms her great love and intimate bond with her husband. At the end of the novella she reflects on how the feeling that she is left with after consummating the affair is perhaps similar to the feeling that children have when they claim to see God.

In The Temptation of Quiet Veronica (henceforth Veronica), Veronica, a virgin, remains in the confines of her home, caring for an elderly aunt and reflects on the relationships with two men, Johannes and Demeter, both of whom have left. Demeter left first when the two men had fought over Veronica and Johannes left after Veronica had rejected his confession of love and refused to go away with him. Johannes indicated that he was leaving to commit suicide. While alone, Veronica remembers the arousal of erotic feelings she felt as a young child when with her dog, acknowledges that she has denied her own sexual desire for Johannes and then, after a night of intense spiritual and mystical dreams and experiences, finds an inner joy with the prospect of Johannes' death. In the end she learns that Johannes is still alive and is coming back, and Veronica is happy at this prospect.

First, let me say, to summarize these two novellas does an injustice. These novellas, considered some of Musil's most abstract and dense work, are particularly written not to simply be read, but rather to be experienced. Musil was interested not in intellectual response but in emotional response (Peacock 255). The external action as briefly described in the plot line above is of secondary import in both of these novellas. Of primary import is the space of internal experiential processes in which these women embrace their identity, culminating in their actions. Literary critics have described these novellas in a variety of ways from being "two exquisitely written stories" (Wilkens and Kaiser 232) to "two of the world's most unreadable stories" (Cohn 154). As author of these novellas, Musil has been negatively described as a "pervert and educational Philistine" (Isitt 244 ) and as putting "queer ideas into women's heads" (Bayley 265 ). If anything, Musil has been successful in his goal of eliciting affect in anyone who completely reads these novellas. In fact, these novellas are meant for what one literary critic calls the "implacable re-reader" (Cohn 154). This is undeniably so.

Upon my first reading of Unions, I was struck, as most readers are, by the language that Musil uses to describe these two women's internal struggles and erotic experiences with a divine presence. For instance, one scholar counted 337 similes - most often comparatives involving animals, bodies, and landscapes - in the brief $3^{8}$ pages of Perfecting (Cohn 157). The many similes in the novellas focus upon the main female character's ethical dilemma between external and internal codes of behavior, between intellect and erotic feeling. Musil's language evokes 
the experience of the deep dichotomy that each main character feels between their body and the outside world. For instance, Claudine, after consummating her affair and beginning to feel pangs of guilt comes to the following revelation: "Yet at the back of her mind, there was a shadow memory of something she had once experienced on a day in spring: a state that was like giving herself to everyone and yet belonging only to the one beloved...." (177, italics in original). In like manner, although coming from the opposite direction, Veronica also speaks of this deep dichotomy at the end of her mystical experience: "Consumed by fever, fine-drawn and thin as a withered rose-petal, she felt herself to have become transparent; and she felt as though her body were everywhere at once and at the same time contracted to such minuteness that it was as if she were holding it in her own tightly shut hand" (216).

Many critics of Musil turn to Freud in examining Musil's literary works and the deep dichotomy expressed above. In particular, Andrew Webber's study, Sexuality and the Sense of Self in the works of Georg Trakl and Robert Musil, ${ }^{3}$ reduces Musil's oeuvre, particularly Unions, to Freudian principals of phallic obsession, hysteria and general self-projection. Yvonne Isitt critiques this type of misguided Freudian focus. She states that rather than attributing it to Freud, Musil's concern reflected "the prevailing attitude to life presented by Austrian literature; the interplay of the magical and the real world in the Zauberstück, the interaction of magic and morality in the Geisterstück" so common in drama (Isitt 244-45). What was unique to Musil is that he transposed this interplay and interaction into the novel. I would agree with Isitt that Musil is indeed drawing on the history of Austrian dramatic literature; however, there is something else that is also occurring in Unions.

In my second reading of the text I began to see that this something else has everything to do with religious identity. In his introduction to the English translation of Musil's diaries, Mark Mirsky states that Musil's The Man Without Qualities (henceforth $M o E$ ) is a "deeply religious work" a kind of "religious drama" along the lines of Homer's Odyssey, the Epic of Gilgamesh, and the Book of Job (XLIII, XLVI). Mirsky continues that it is this religious quality that distinguished Musil from other early postmodern writers of the day who claimed no truth or no transcendence, only relativity and flux. Musil found the idea of an eternal presence, the divine, the supernatural, if you will, not only positive, but of much use in a world in which the social and political centers were slowly fading. Musil is described as one of those "few writers whose work seems to hold wisdom, the secrets of one's own questions about Eros, political direction, and religion; what the pious of all religions would call 'the Unknown' or 'other reality'...." (XXXVII). Hence I intend to explore the possibility that Musil, in writing Unions, was 
consciously in dialogue with various religious economies present in the early twentieth-century European landscape. On the one hand, in reaction to the growing feminist movement sweeping across Europe in the late nineteenth and early twentieth centuries - particularly Feminist Socialism as led by such women as Adelheid Popp-Dworak in Austria and Clara Zetkin in Germany - the Roman Catholic Church was tightening its traditional stand on approved female roles for women, such as wife, mother, and nun. ${ }^{4}$ On the other hand, scientific inquiry into human experience was being hailed as making religion obsolete, particularly in the new psychoanalytic community represented most notably in the works of Sigmund Freud. In Freud's 1899 publication, Interpretation of Dreams, the focus was upon the unconscious mind and the difference between reality and illusion. The tenants of this religious cartel included his 1895 Studies in Hysteria, his subsequent [mis]diagnosis of Dora, one of the most well-known case studies in the history of psychoanalysis, which led many others to [mis]diagnose the illness of hysteria in other women and thus discount, denigrate, if not pervert, women's experiences of their bodies, their sexuality and their erotic fantasies, and culminated with Freud's The Future of an Illusion in 1927, which contended that any concept of the divine is just that, an illusion, and, more often than not, tied to sexual neuroses.

Given the various religious economies circulating in Musil's intellectual environment, we can understand the function of Unions in terms of what Mieke Bal calls an "efficient ideological weapon," that is, a text supporting one's views and triggering a reaction in the reader (132). Bal concludes that there is no "one" truth to any reading of a text, and for this very reason, "women can creep" into a text and "rewrite themselves back into the history of ideology" (132). Or, as Nietzsche stated above, these perfect women can perpetrate a text. Musil represents in Unions, I believe, another option to the religious economies above. Musil's religious economy included spaces of mystical embodied experiences of the divine that were sexual, sensual, beyond scientific, empirical certainty and that often transgressed accepted moral and ethical codes of behavior. Can adultery lead to a perfecting of a marriage? Musil emphatically stated yes. Can fantasizing about bestiality, denying physical sexual contact, and rejoicing at the thought of a loved one's death cause that love to grow? Musil emphatically stated yes. Are these women sick or delusional? Musil, I think, emphatically stated no.

In this light, we can, for example, explore the function of Veronica's fantasizing about bestiality to illustrate my point. Veronica declares at one point to Johannes:

I understand her so well.... The peasant woman... She never had a lover again, only those two big dogs of hers. ... but just try to imagine it: those two huge beasts, sometimes 
standing up on their hind-legs, their teeth bared, insistent, masterful, as though you were just the same as they are - and somehow you are.... It's not an animal's desire, but a desire coming from something else that I can't find any name for. And I don't know how it is that I can understand it so well. (186)

Johannes responds, "But all this is sin! Such talk is filthy!" And perhaps most readers of this text find Johannes's response rational and appropriate. However, when we examine this text in the context of another text by Musil, Veronica's musings become more than simply filth, sin or "queer ideas in women's heads."

In a diary entry dated 24 April 1907, Musil relates a story about a woman in Carinthia, Austria, the province of Musil's birthplace. This woman was rumored to have an intimate relationship with her mastiff. Musil's diary entry reads, "In the angry arousal of such an animal there is something that may well stimulate a woman. It is also possible that one feels loathing for men and prefers dogs - such a feeling is possible, precisely with women who love their integrity" $(113) .^{5}$ This is Veronica, our literary heroine created by Musil two years later. Disturbing as it may be for those reading Veronica's musings on bestiality in 1911 or for those of us reading about it almost a hundred years later, Musil, I believe, includes a story in actual oral circulation in Austria in order to illustrate an important point in his religious economy - the unsettling possibility that the preference a woman might have for a dog over a man is not a sign of diseased sexual fantasy or unholy perversion, but rather an erotic experience which not only maintains a woman's integrity, but in the end, provides access to the divine. For Musil, women were operating out of this unconventional morality, if you will, and leading the way in an alternative economy to the dogmatic institutional religions or the popular psychoanalytic professions. Women's bodies, their internal yearnings, their outward expressions and their ultimate union with Geist, spirit, god, what have you, is the vehicle through which Musil's religious economy is had. To Musil, women were not lethal - as the Roman Catholic Church would contend and as Bal illustrates so clearly in her examination of biblical readings of women's roles as temptresses and whores, and of women's sexuality a thing to be avoided, save for procreation - nor were women ill and their sexuality (or their fantasies about sex) a symptom of deep and disturbing neuroses.

As represented in Unions, women were sensuously powerful, saw beyond the surfaces to an often unsettling depth, expressed unabashedly their sexuality, and understood that transgressions and denials must sometimes be made in order to perfect a divine, transcendent union, even if only temporarily. In short, corporal and spiritual dimensions are entwined in Musil's moral and ethical landscape, which embraced a deep skepticism "toward the conventional in all its aspects" (Mirsky XLIII) and required that women and their bodies transgress or deny 
certain moral certainties. However, I am not advocating that Musil was an early feminist writer. While he rejects the gendered traditions of both poles of the religious economy to which he is reacting, Musil's alternative also includes nonetheless gendered constructions of power.

Musil's gendered notion of access to the divine illustrates what Pierre Bourdieu calls the official and unofficial gendered practices of power and spaces (Bourdieu 41). While men officiate their spiritual power in public within the realm of an institutional organization, women must unofficially practice their clandestine "magic" in private. In short, women's power comes from their private experiences of erotic intercourse with the divine. And, this intercourse often entails transgressing or denying conventional codes of behavior. This establishes a social and symbolic order according to gender (Bourdieu 93ff). In short, Musil's literary women transgress boundaries or deny conventional codes of behavior in order to access the divine. In accessing these women (be it via sexual intercourse or via the reading of a text in which these women have crept in), men are able to access the divine by proxy. The gender constructed from this dynamic relationship establishes, then, "social relationships based on these perceived differences between the sexes," and thus signifies "relationships of power" (Scott 42). Musil's gendered religious economy integrated psychological states in which an individual would merge with the entire universe, not simply at a mental level, but at an emotional, physical as well as spiritual level. Musil used the expression "der andere Zustand" (the "other" condition) to refer to "mental states in which the selfhood of the individual merges with the universe as a whole"; it represented "something of a mystical quality" and is considered central to Musil's thinking (Diaries 524, fn 1; 525, fn 13). Some attribute Musil's interest in this "other" condition to the fact that his chosen professions - soldier, engineer, academic psychologist - prior to committing himself to a life as a writer were all consumed with demands of "manhood" as constructed in Europe (and of course elsewhere) at the time, namely the demands of "objectivity, self-discipline, asceticism of the body and mind" (Payne XXVIII). And here is where we can see clearly the construction of gender and religious identity in Musil, and in Unions in particular. Women's sexuality and their transgressive nature are the way to transcendent union with god. Men need these women in order to break off, or rather balance, the "demands of manhood" as described above. In Musil the relationship of power is this symbiotic relationship of male and female becoming one - whether it be a hermaphrodite or androgynous is irrelevant.

Musil's literary characters in general "will toward another existence, a life in which there are no boundaries of gender but an ecstatic wholeness, a submersion of two partners in a boundless Unknown" (Mirsky XLI). This same "will toward 
another existence" is operative and one of the guiding motivations of action for both Claudine and Veronica. Both women want to experience this ecstatic union. Claudine does it by committing adultery, Veronica via bestial fantasies and mystical communion with a man she believes to be dead. These women represent two poles of ecstatic union - transgression and asceticism. In this way both Claudine and Veronica are on the margins of moral and ethical society. As one commentator states:

If you are curious about the forbidden, the taboos of society, and regard fiction as a way of exploring the boundaries of consciousness, Musil becomes irresistible. What constitutes evil? The reality of nationalism, the meaning in erotic and mystical awareness - these are the questions of his essays, shorter fiction, and novels. (Mirsky XXXVI)

Via his narrative, Musil explores the taboos of his society and brings them from margin to center and demands that the reader not only read this experience but also "feel, smell and live through" (Mirsky XXXVIII) these transgressive experiences.

In particular, Musil was interested in transgressions which would create another moral system. Often, when examining $M o E$, commentators and critics will point to the irony in characters whose actions permit that which is forbidden: namely, a transgression or denial that is transformed into deep mystical love (Mirsky XLII). It is obvious, however, that these elements of irony are central to the novellas of Unions and that the notion of transgression, with elements of a Buddhist or Kabbalist sensibility, is present throughout. Bernard Faure points out in his study of Buddhist approaches to sexuality, particularly Tantric Buddhism, that within this religious system, "apparent transgressions may end well" (282). Cleaving to Bataille's notions of taboo and transgression, Faure continues, "Transgression is the very movement of spirituality: to exceed all limits, to abide nowhere.... It is a constant violence to or violation of the homeostatic tendency of human nature, an ex-stasis, excess, hubris" (282). Transgressions produce an exstasis that places one beyond human experience in the realm of religious, otherworldly experience.

Faure also points out that female transgression has, more often than not, been kept silent historically. Acknowledging female transgression would permit "women to break through the boundaries of male discourse ... female transgression has to remain invisible or unthought, it has to be made irrelevant, if women are to be kept in a subaltern position" (138-39). In both novellas, Musil breaks this conspiracy of silence by allowing these women to perpetrate a text and speak publicly about transgressive behavior that leads to religious ecstasy. Instead of keeping the women and their experience in a subaltern position, on the margins, Musil moves women and their transgressions (whether it be the sexual 
transgression, as with Claudine, or the structural opposite, ascetic denial, as with Veronica) front and center. Musil does not use these texts of female transgressions as cautionary tales to extract proper behavior (as a sort of interdiction), as the Roman Catholic Church might have, nor does he employ them as psychoanalytic studies in order to expose deep neurotic neuroses, as Freud might have. Musil acknowledges that women's transgressions illustrate an alternative moral and ethical space in which one could live.

It is at this point that I must pause to ask about Musil's world and possible influences on these two unique and exhaustingly abstract novellas about women's deepest erotic and spiritual experiences. What influenced Musil's ethical, moral, in short, religious perspectives? This leads, then, to the context in which Musil was writing.

Born to an Austrian father and Bohemian mother, Musil spent his early years in both Austria and Bohemia. After attending military boarding school, Musil embraced the many aspects of fin de siècle narcissism early in his life while studying engineering in Brünn/Brno. Musil himself wrote later in life, "my generation was anti-moral or amoral because our fathers talked of morality and behaved in a philistine and immoral fashion" (cited in Payne, XXIII). The hypocrisy and stated moral rigidity of the bourgeois attitude is what Musil was reacting to in his literary works, something which also found its way into his diary: "I accept and enjoy every kind of sensual experience without any form of restraint" (Diaries 16). ${ }^{6}$ As one scholar surmises in his reflection on Musil's literary subjects, "Is it possible to create another morality in a secular age that will bring us into an experience beyond this particular time and age?" (Mirsky XXXVI). This interest in creating an alternative ethical and moral world prompted Musil, after graduating with an engineering degree and working for one year as an academic engineer in Stuttgart to begin studies in psychology and philosophy at the University of Berlin (1903-1908). Under the direction of one of the leading scholars in experimental psychology, Dr. Carl Stumpf, Musil not only began to learn to scientifically observe other human beings, but also turned the microscope upon himself and those he knew best. Musil used empirical observations and scientific precision in his creative writing as well and published his first novel, Die Verwirrungen des Zöglings Törleß (The Confusions of Young Törless) in 1906, two years before he would complete his doctorate in philosophy. ${ }^{7}$ Young Törless gained critical acclaim, and after graduating, Musil turned down a prestigious academic position in Graz to focus upon his writing. It was during this time that Musil began to write Unions. ${ }^{8}$ He was commissioned in 1909 to write a piece after an editor had read an early version of Veronica in a 1908 periodical and asked Musil to compose 
a companion piece for the edited article. (Hickman 57) ${ }^{9}$ Musil readily agreed and Unions was published two years later, in 1911.

As noted above, Musil developed his literary craft by using the skills of dissection and observation in his own life. Young Törless is an autobiographical sketch of Musil's early life in military boarding school, and it is common knowledge among those familiar with Musil that he dissected his own life for this first novel. ${ }^{10}$ For his second novel, Unions, he dissected a woman's life.

Musil met Martha Marcovaldi in 1907. Martha was six years older than Robert and was married to her second husband when they met. Martha and her children left her husband, and Robert and Martha became quickly inseparable. Although they were living together, Martha was not able to secure a divorce and marry Robert until 1911. They remained together for the rest of their lives, sharing "intellectually and spiritually as one organism" (Payne XII). While there are many relevant details of both Martha's individual life and their life together for the purposes of this examination, I will focus only upon her direct influence on the writing of Unions.

Unions is not only very intense for the reader but was very straining for Musil. ${ }^{11}$ It is also one of his most concentrated works, and "from the point of view of taxing his abilities as a writer ... was probably the most difficult Musil ever undertook" (Isitt 245). Musil himself described it as "despairing work" (cited in Isitt, 244).

Musil and Martha had been together only a year when he published the first version of Veronica. Hickman reveals that Martha, like Veronica, lived in a home with an elderly aunt and four male cousins, one of whom became her first husband (59). This is the framework from which Musil created the first of the novellas. While they shared a deep and mutual intimacy from the beginning, early in their relationship, Martha went to visit a former fiancé and ended up having a brief affair with him. Again, most scholars agree that this episode is the foundation for Perfecting. ${ }^{22}$ One scholar, however, sees the motivation for the composition of this second novella as Musil's "revenge" for this affair and to "interrogate Martha on her feelings before, during, and after her infidelity," making this interrogation itself the subject of the novella. ${ }^{13} \mathrm{I}$ am not convinced that it was revenge Musil was seeking in composing this second novella. Unconventional, transgressive sexual behavior was not foreign to Musil. For one thing, Martha assisted in the composition of these two novellas. There are diary entries which Musil made beginning in August of 1910 that indicate Martha's assistance in both the editing and compositions of Veronica and Perfecting (Diaries 116ff). In addition, Musil's autobiographical first novel includes both homosexual and heterosexual experiences, at least one with a prostitute (Payne X). Musil also had 
a love affair prior to meeting Martha with a "working class girl" (from whom he became infected with syphilis) that would be the basis of another later novel (Tonka), in which one can also see, as in Unions, that the "borders between sexuality and love are fluid" (Payne Xxv). And finally, Musil's own mother had a forty-year male liaison, who lived in the home (Musil's father apparently accepting the situation) and whom Musil was told to call "Uncle" (Peacock 254). Hence, I do not see these two novellas, and Perfecting in particular, as a type of revenge for unconventional sexual behavior. I view them as a type of interrogation that one might find in a confession; I see Musil as an interlocutor extracting a confession of Martha's experiences - her feelings, inner struggles and subsequent revelations concerning her affair, which are then put to paper. What is the function of this confession?

In The History of Sexuality, vol. I, Michel Foucault provides the historical context in which we can move beyond revenge and better display the function of confession in Musil's Unions. Foucault's classic analysis of modern European sexual history pinpoints several social and mental mechanisms that caused the public discourse of sex to be of import. In particular, Foucault points to the confession as a pivotal moment in which power relations are established and disseminated within European sexual discourse. Foucault illustrates that the infinite task of telling one another about our sex lives, via confession, while having a long history in ascetic and monastic life, had become a standard "rule for everyone" (20) by the seventeenth century. This required discourse, Foucault continues, was particularly important in the Christian pastoral economy, which expanded into the public realm in the eighteenth century. By the nineteenth century sexuality had become a standard part of the discourse of the medical establishment. Hence, whether in religious, political, social or medical settings, by the time Robert Musil was writing, "one had to speak of sex" publicly (Foucault 24). We can view other writings, such as Freud's publications and case studies, in this light as well. One can posit that psychoanalytic case studies are also a secular form of confession. Foucault contends that the obligation, if not requirement of confession had everything to do with the exercise of power. Foucault illustrates that in western European sexual discourse there have been "two great procedures for producing the truth of sex" - ars erotica and scientia sexualis. Societies such as China, Japan, India, Rome, and the Arab world embraced an "ars erotica that experienced pleasure as the space in which truth can be found and that its particular intensity would be in its reverberations in the body and the soul" (57), while "our civilization," as Foucault refers to the European continent, practices what he calls scientia sexualis. It is a civilization, which has developed the "procedures for telling the truth of sex which are geared to a form of knowledge-power strictly 
opposed to the art of initiations and the masterful secret as expressed in ars erotica" (58). This tradition, Foucault continues, relies on a "production of truth," the most valued techniques of which became the confession, in which "one admits to oneself, in pleasure and in pain, things it would be impossible to tell to anyone else, the things people write books about" (58-59). The efficacy of this production of truth via scientia sexualis comes not from the confessor but from the one who listens - the priest in religious settings, the psychologist in psychoanalytic settings, the judge in legal settings and, for the purposes of our examination, the scribe in a literary setting, and finally the reader.

I believe Musil was using both of these productions of truth in his literary representation of his wife's confessions. In one sense, he embraces the ars erotica; as one scholar puts it "the eroticism of marriage is terra incognita for Western literature. Perhaps Musil has unwittingly approached it closer than anyone else."14 Yet Musil presents it via the process of scientia sexualis, whereby those who listen to (or rather read) the confession provide its efficacy. While of course Musil did not have Foucault's writing from which to draw inspiration (lest you think for a moment I am anachronistic), there is another contemporary text from which Musil does draw, I believe, his notions of confessions of ecstatic experiences.

Musil was influenced by the great panoply of nineteenth- and early twentiethcentury intellectual life, many of whom he knew personally: Nietzsche, Emerson, Wittgenstein, Thoreau, Stendhal, Marx, Jung, Maeterlinck, Lévy-Bruhl, Hegel, Mann (both Heinrich and Thomas), Schiller, Wundt, Dilthey, Dostoevsky, Rilke, Kafka, Lukács, Tolstoy. ${ }^{15}$ Much could and has been written on how these various thinkers influenced Musil's life, literary craft and his interest in mystical eroticism, particularly Nietzsche and Emerson; however, I would like to examine the work most biographers of Musil point out was Musil's "bible" and which I believe had a particular influence upon the composition of Unions: Martin Buber's 1909 collection Ekstatische Konfessionen (Ecstatic Confessions). ${ }^{16}$

Musil's obsession with Ecstatic Confessions was acknowledged in a 1985 English translation of Buber's collection:

No one perhaps read Ecstatic Confessions as carefully as the Austrian novelist Robert Musil, who kept a special copybook in which he transcribed numerous excerpts from Buber's collection. These excerpts later served Musil in the composition of the many excursuses on mysticism in his novel The Man Without Qualities. (XIX)

I would argue that Buber's collection was one of the primary frames in which Musil worked in crafting Unions. In addition, most literary critiques constantly evoke $M o E$ when discussing any influence of Ecstatic Confessions on Musil's literary works, as Paul Mendes-Flohr did above, and, perhaps, rightly so, in that around 300 citations of excerpts from Buber's book are said to be within $M o E$ 
(Mirsky XLIX). There is also speculation that Musil's seeking the unknown via the erotic could also have been influenced by the thirteenth-century neo-Platonic Jewish Kabbala document, The Zohar, and Dante's Commedia (Mirsky XuIX). A 1988 review in the New York Review of Books of a new English translation of Musil's works states, "The most graphic passages in all his books deal with sexual musings and intimations as a part of the other condition, the state that medieval mystics, in whom Musil was much interested, frequently likened to certain kinds of erotic experience" (Bayley 263). I would argue that one can see the direct influence of Buber's collection, if not the Kabbala and Dante as well, in Unions. When examining Unions with this in mind, one can see that Musil's novellas have everything to do with religious identity and gender construction based on mystical, ecstatic confessions along the lines of Foucault's ars erotica and scientia sexualis.

Buber's collection includes voices of mystical encounters from a wide variety of cultures and historical periods-from the great Indian epic Mahabharata (c. 400 BCE-300 BCE) and Lao-Tse (c. 300 BCE) to eighteenth- and nineteenthcentury European mystics. Buber states his book represents the vox humana and that orderly explanations are not of import:

The ecstatic individual may be explained in terms of psychology, physiology, pathology; what is important to us is that which remains beyond explanation: the individual's experience. We pay no heed here to those notions which are bent on establishing 'order' even in the darkest corners; we are listening to a human being speak of the soul and of the soul's ineffable mystery. (XXXI)

I would argue that in this passage Buber expresses exactly what Musil intended to be the function of Unions. Musil was also not interested in orderly explanations of the psychology, physiology or pathology of his characters. Unions is, above all, a literary work in which the reader listens to women speak of the soul and of the soul's ineffable, inexplicable, mystery. It is of import in illustrating the influence of Buber's work on the novellas, in that the overwhelming majority of confessions in Buber's collection, particularly from Central Europe, are those of women.

There are two hauntingly familiar confessions in Buber's collection in particular that, on the surface at least, evidence similar concerns with both Claudine's and Veronica's. These two medieval confessions are part of a larger corpus entitled, "From the German sister-books (thirteenth and fourteenth centuries)." These two sisters, Sofia von Klingnaur and Jützi Schultheiss, are uncannily similar to the other "sisters," Claudine and Veronica. Buber states in his forward that Sofia "could experience only herself (but not something particular about herself, rather her entire I in everything)" while Jützi "could experience only the world (but not this, that, or the other thing in it, rather the whole world 
in everything). They experienced the same thing, and yet how differently!" (XXXIV-XXXV). Buber's declaration here is, I believe, also a description of Claudine (read Sofia) and Veronica (read Jützi), who both have come to the same conclusion, via different routes, particularly in the passages of the novella cited above regarding the deep dichotomy each woman feels. This intertextuality between Unions and Ecstatic Confessions takes on even more weight when reading the confessions themselves. For instance, the confession of Sofia, who is about to die, begins with a reflection on her former life and how much time she "had spent in the world in frivolous pursuits" $(81)$. This is indeed what Claudine reflected upon during her entire trip prior to her affair and subsequent ecstatic union with the divine. The confession of Jützi begins with the simple statement, "Then God decreed a great temptation for her, that she thought and it became her opinion that she should never see God" (85). The Temptation of Quiet Veronica echoes this decree. There are also uses of similes comparing their bodies to landscapes and other elements that are utilized within Unions, as discussed above. While I realize these constructions within confessional narratives are not unique, the pairing that Buber expresses in the forward and the subsequent similarities of these two confessions to the two novellas of Unions may very well be related.

One can also see the influence of Jewish mysticism in Unions by pointing to one of the verses excerpted from the Hasidim in Ecstatic Confessions:

Whoever greatly desires a woman and contemplates her brightly colored garments has his mind not on the gorgeous cloth or colors, but on the splendor of the desired woman who is enveloped in them. But the others see only the garments and nothing more. So whoever desires and receives God in truth beholds in all the things of the world only the power and the pride of him who shaped them at the primal beginning, and who lives in things. But whoever is not on this level sees things as separate from God. (149)

This verse indicates a gendered and embodied notion of the divine that is sexual in its nature. One desires God in the same way that one desires the splendid unclothed body of a woman. And of course it is of more than passing interest to note that both Claudine and Veronica, in the midst of their most transformative mystical unions, take their garments off and stand naked - or rather are on all fours on the floor - allowing that divine presence to "behold" them in their primal beginnings. While I have yet to find any scholarship on Buber's influence on the writing of Unions, his influence on $M o E$ has been noted (see Goltschnigg), which serves to support my basic premise that Buber's collection is a frame in which Musil is working.

In short Ecstatic Confessions is a study of comparative religious experience that counters the scientific, and psychoanalytical, if not pathological, writings gaining currency in the Central European religious economy of the nineteenth 
century, which, more often than not, tagged women as ill and their sexuality as somehow dangerous. Musil was never persuaded to accept the psychological theories of Freud, Schnitzler, and Wedekind "as a fundamental means of analyzing the human psyche" (Islitt 247). Unions represents Musil's reaction against these sterile and scientific interpretations of women's inner religious experience. As an ideological weapon, Musil's novellas offer an alternative space of religious identity within the early twentieth-century Central European religious economy. In his examination of $M o E$ and the construction of modern identity, Stefan Jonsson contends that Musil's magnum opus should be "situated among a series of other projects of the same period that sought to explain the political role of affections and the suggestive power of nationalism and fascism." ${ }^{17}$ I agree with Jonsson's assessment of $M o E$, and I similarly situate Unions, as an ideological weapon, in order to explain the gendered role of affections within the religious economic landscape of the early twentieth century.

In situating the analytical frame of Foucault's confessions and the influence of Buber's collection, we can now see the function of Unions as expressing power relations not only between Robert and Martha Musil, but also relations of power between the characters within the novellas. We can also understand the relations of power that Musil was reacting against within his intellectual heritage of science and psychology, that of "radical empirical skepticism" which considered highly suspect any notions of harmony and union. ${ }^{18}$ Musil is embracing a space of identity that insists on acknowledging a transcendent world that is beyond scientific empirical proof or psychological stereotypes. He would deny that religion was an illusion, as Freud later contended. In short, Musil is arguing against the view that sexuality, of women in particular, is nothing but repressed neuroses often manifesting itself in various illnesses such as hysteria. Rather Musil is representing in his work a sexuality that is inextricably tied to a gendered religious identity that embraces a mysterious other. In short, Musil's religious economy is one in which women's bodies and their experiences, particularly their erotic experiences, as told, as confessed, as perpetrating texts, are access to the divine.

The artistry of Unions emerges, as I have shown here, when one situates Martin Buber's Ecstatic Confessions next to Musil's text and reads it within the context of Foucault's historical analysis of the confession. When properly framed and adequately displayed, Unions provides an important portrait of one space of gender construction and religious identity in the early twentieth-century religious economic marketplace. Musil himself felt that Unions was inadequately understood and inappropriately displayed. In a diary entry made late in his life, he pointed out that what was wrong with Unions was "that it is a book. That it has a binding, spine, pagination. One ought to lay out a few of its pages between sheets 
of glass, then change them from time to time. Then one would see what it is" (Diaries 205). Like so many relics of a saint displayed at a pilgrimage site, Musil wanted the ecstatic confessions of his wife to be adequately displayed or noticed in the way that he intended. And it is here that we must return to Nietzsche, as Musil did so often in his life:

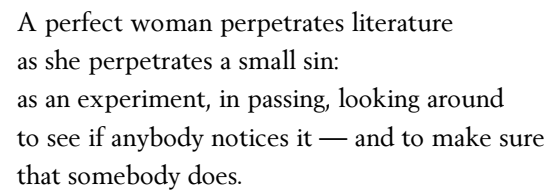

Robert Musil wrote these two novellas about perfect women, perpetrating literature, perpetrating small sins, creeping into a text as an experiment. For Musil, the experiment was in giving positive voice to a woman's confession of a mystical, ecstatic, sexual identity in the early twentieth century. He and Martha did this, almost in passing, wondering if anyone noticed. And in the waning days of his life, Musil acknowledged that Unions was the only one of his literary works that he enjoyed re-reading occasionally (Hickman 66), he himself being that implacable re-reader. Musil was making sure that at the very least somebody noticed a perfect woman perpetrating a text. I noticed it.

\section{W ORKS CITED}

Anderson, Bonnie S. and Judith P. Zinsser. A History of their Own: Women in Europe. New York: Harper \& Roe, 1988.

Bal, Mieke. Lethal Love: Feminist Literary Readings of Biblical Love Stories. Bloomington: Indiana University Press, 1987.

Bayley, John. "Death and the Dichter." In Peacock. Bourdieu, Pierre. Outline of a Theory of Practice. Cambridge, UK: Cambridge University of Press, 1977.

Buber, Martin. Ecstatic Confessions. Trans. Paul Mendes-Flohr. San Francisco: Harper \& Row, 1985 [1909].

Cohn, Dorrit. "Psyche and Space in Musil's Die Vollendung der Liebe." The Germanic Review LXIX.2 (March 1974)

Faure, Bernard. The Red Thread: Buddhist Approaches to Sexuality. Princeton, NJ: Princeton University Press, 1998.

Foucault, Michel. The History of Sexuality, An Introduction, vol. I. Trans. Robert Hurley. New York: Vintage Books, 199 .

Goltschnigg, Dietmar. Mystische Tradition im Roman Robert Musils: Martin Bubers "Ekstatische Konfessionen" im "Mann ohne Eigenschaften." Heidelberg: Lothar Stiehm, 1974. Robert Musil \& the Culture of Vienna. London \& Sydney: Croom Helm, 1984.

Isitt, Yvonne. "Robert Musil." In Poupard.

Jonsson, Stefan. Subject Without Nation: Robert Musil and the History of Modern Identity. Durham \& London: Duke University Press, 2000. 
Mirsky, Mark. “Introduction.” Diaries I899-I94I. Robert Musil. New York: Basic Books, 1998.

Musil, Robert. Diaries, I899-I94I. Selected, translated, and annotated by Philip Payne, edited by Mark Mirsky. New York: Basic Books, 1998.

-. Unions. Trans. Eithne Wilkins and Ernst Kaiser. Preface by Frank Kermode. Boston: Verba Mundi, 1966.

Payne, Philip. "Preface," Diaries I899-I94I, Robert Musil. New York: Basic Books, 1998.

Peacock, Scott, ed. Twentieth-Century Literary Criticism, vol. 68,. Detroit, London: Gale Research, 1984 .

Poupard, Dennis, ed. Twentieth-Century Literary Criticism, vol. 12. Detroit, London: Gale Research, 1984 .

Rogowski, Christian. Distinguished Outsider: Robert Musil and his Critics. Columbia, SC: Camden House, Inc., 1994.

Scott, Joan Wallach. Gender and the Politics of History. New York: Columbia University Press, 1988.

Stark, Rodney and Roger Finke. Acts of Faith: Explaining the Human Side of Religion. Berkeley: University of California Press, 2000.

Webber, Andrew. Sexuality and the Sense of Self in the Works of Georg Trakl and Robert Musil. London, England: Modern Humanities Research Association for the Institute of Germanic Studies, 1990.

Wilkins, Eithene and Ernst Kaiser. Essay, 1952 In Poupard.

\section{E N D N O T ES}

1 See Rogowski, Hickman, and Jonsson.

2 This concept was borrowed and developed from Talcot Parsons's 1951 The Social System.

3 While Webber does reveal certain crucial aspects of Musil's literary craft, Webber ignores the point of what I will show was Musil's primary inspiration for the novellas - women's confessions of a deep religious, sexual, and mystical union with god.

$4 \quad$ See Anderson and Zinsser, 354, 372, 383.

5 It is important to note that the English translation of Musil's diaries are only two-fifths of the German original. I am obviously hindered from not having these originals available to me.

6 The editor admits that these early entries can be anywhere from 1899-1904 or later.

7 See Hickman 190. Musil's dissertation was on the epistemology of the physicist and philosopher Ernst Mach, who deeply influenced Musil's interest in, among other things, mysticism. This section also owes a great deal to Payne.

8 Unfortunately, the reception of Unions falls outside the parameters of this study formed, as they are, by the context in which Musil produced literary work and the way Musil's literary work sheds light on early twentieth-century religious economies. A fascinating line of inquiry would be to explore whether there were significant differences in reception according to gender or whether there was any reaction from the institutional church or the psychoanalytic community.

9 The earlier article which included elements of Veronica was entitled "The Enchanted House." 
10 See Hickman, Jonsson, and Rogowski.

11 See Payne xii, and Hickmann $57 \mathrm{ff}$.

12 See Hickmann, Jonsson, and Rogowski.

13 See Payne's preface, xxvii. I disagree with Payne's assessment of this "eye for an eye" attitude of Musil, who later had an affair while in Italy, and put this experience down in the narrative of "Girgia."

14 Denis De Rougement as quoted in Mirsky, xli.

15 It should also be noted that another possible influence on Musil was his second cousin Alois Musil (1868-1938), Old Testament professor and Arabic scholar at the University of Vienna who was a spy in the Middle East during WWI for the Austrian intelligence. I found one very brief reference to him; however, more research on their relationship, which includes written correspondence would, I think, be an interesting inquiry. See Mirsky Liii.

16 See Jonsson 23, Rogowski $158 \mathrm{ff}$, and Hickmann 160.

17 Jonsson 261. He also contends that $M o E$ should not be compared to, among other things, Buber's theology. I am arguing, of course, precisely the opposite, that Buber's theology assisted Musil in formulating explanations.

18 Genese Grill, as quoted in Mirsky 1. 